\title{
NOTE
}

\section{DIPHOSPHOPYRIDINE NUCLEOTIDASE OF MURINE LEPROSY BACILLI}

Previously, this author (1958) reported that diphosphopyridine nucleotide (DPN) stimulates the endogeneous metabolism of murine leprosy bacilli under anaerobic condition, but the stimulating mechanism of DPN is not yet clarified. Therefore, as an attempt to elucidate this mechanism, an investigation was made to examine the existence of diphosphopyridine nucleotidase (DP-nucleotidase) in the bacilli.

Murine leprosy bacilli were collected from the rat lepromas by the same method as the previous report (Kusaka, 1958). DPN and DP-nucleotidase were determined spectrophotometrically by the method of Kaplan et al. (1951).

Results shown in Table reveal that DP-nucleotidase does exist in the bacilli, and that the enzymatic activity of bacillary extract is higher than that of bacillary suspension, which may be explained by permeability of the bacillary membrane against DPN.

Table 1. Determination of diphosphopyridine nucleotidase activity in murine leprosy bacilli

\begin{tabular}{lcc}
\hline $\begin{array}{c}\text { Bacillary preparation } \\
\text { used }\end{array}$ & $\begin{array}{c}\text { Incubation period } \\
\text { at } 37^{\circ} \mathrm{C} \text { (hour) }\end{array}$ & DPN split $(\mu \mathrm{M})$ \\
\hline Suspension & 1 & 0.21 \\
Suspension & 2 & 0.38 \\
Supernatant of extract* & 2 & 0.64 \\
Sediment of extract* & 2 & 0.00 \\
\hline
\end{tabular}

Tube contents (total volume, $1.5 \mathrm{cc}$ ) : $0.6 \mu \mathrm{M} \mathrm{DPN}, 40 \mu \mathrm{M}$ phosphate buffer $(\mathrm{pH}, 7.3)$ and the bacillary preparation (corresponds to $5 \mathrm{mg}$ dry weight of bacilli).

* The bacillary extracts were prepared by the destruction of bacillary membrane with sonic oscillator as described in the previous paper (Kusaka, 1958), and centrifuged at 5,000 g for 40 minutes.

Enzymatic activity (supernatant of the extract) : $0.064 \mu \mathrm{M} \mathrm{DPN}$ split/hour at $37^{\circ} \mathrm{C} / \mathrm{mg}$ dry weight of the bacilli.

Kaplan et al. (1951) found DP-nucleotidase activity in Neurospora crassa at the rate of $7 \mu \mathrm{M}$ of $\mathrm{DPN}$ split $/ \mathrm{mg}$ protein $/ 7.5$ minutes at $37^{\circ} \mathrm{C}$. Mcllwain and Hughes (1948) also found it in Streptococcus faecalis at the rate of $0.4 \mu \mathrm{M}$ DPN split/ mg dry weight of cells/hour at $37^{\circ} \mathrm{C}$. Thus, it can be said that the DP-nucleotidase activity of murine leprosy bacilli (Table) is considerably low in comparison with that of Neurospora or Streptococcus. It is possible, however, that some amount of DPN which originates in murine leprosy bacilli is split by this enzyme in the: 
course of the anaerobic experiments and the supplement of DPN becomes necessary for these experiments. Further elucidation of the stimulating mechanism of DPN on the anaerobic metabolism of murine leprosy bacilli should be undertaken in future.

\section{REFERENCES}

Kaplan, N. O., Colowick, S. P. \& NASON, A. (1951): Neurospora diphosphopyridine nucleotidase. J. Biol. Chem., 191, 473-483.

KuSAKA, T. (1958): Studies on the metabolism of murine leprosy bacilli. II. Substances, contained in mitochondria extract of rat liver, which stimulate the metabolism of bacilli and some enzyme systems in the bacilli. Jap. J. M. Sc. \& Biol., 11, 287-293.

McIlwain, H. \& Hughes, D. E. (1948): Decomposition and synthesis of cozymase by bacteria. Biochem. J., 43, 60-70.

National Institute for Leprosy

TAKASHI KUSAKA

Research, Tokyo

Received: December 27th, 1958

日下喬史 (国立らい研究所) 